УДК 621.798

\title{
DETERMINATION OF RATIONAL PARAMETERS FOR ENSURING THE SUSTAINABILITY OF THE TRANSPORT PACKAGING BY METHODS OF INCREASING THE FRICTION FORCES BETWEEN LAYERS OF PACKAGED ITEMS
}

\author{
A. Derenivska, L. Kryvoplias-Volodina, S. Tokarchuk \\ National University of Food Technologies
}

\begin{abstract}
Key words:
transport package, transport package making machine,

strapping means, sustainability,

layer

Article history:

Received 31.08.2020

Received in revised form 10.09.2020

Accepted 30.09.2020

Corresponding author: anastasya.d@gmail.com

ABSTRACT

The problem of ensuring reliable sustainability and strength of transport packages is a priority in the system of end-to-end transportation of packaged items.

The sustainability of the transport package depends on: the method of stacking packaged items on the pallet; physical and mechanical parameters of packing material and means of packing forming; methods and means of strapping the transport package; accuracy of operations of transport package making machine; strength of transport package and consumer packaging, that limits height the transport packages.

The goal of the research was to determine the characteristic parameters that ensures the mutual movement of packaged items and ensure the sustainability of the transport package during loading and unloading transporting operations and storage operations. The subject of research was new packaging material, a cardboard flat for preventing slipping packed items, "Non-Slip Safety Grip for Pallets". Tasks of the research - analysis of existing and selection of rational packaging technologies, development of the force loading scheme for transport package layers; determination of friction forces and inertial components for packed item layers during transporting operations; determination of the limit values of the friction coefficients, which arise between the packed item layers of and will ensure the stability of the transport package.

Using this method of increasing the friction force between packaged item layers allows us to make a rationally choice to prevent the sliding of packaged item layers, to introduce a simplified scheme of the technological process, and to reduce the time of the kinematic cycle. There is no need to use different methods of stacking packaged item on the pallet and to spend time for using additional strapping material for the transport package.
\end{abstract}

DOI: $10.24263 / 2225-2916-2020-27-14$

(C) А. В. Деренівська, Л. О. Кривопляс-Володіна, С. В. Токарчук, 2020 


\title{
ВИЗНАЧЕННЯ РАЦІОНАЛЬНИХ ПАРАМЕТРІВ ЗАБЕЗПЕЧЕННЯ СТІЙКОСТІ ТРАНСПОРТНИХ ПАКЕТІВ МЕТОДАМИ ПІДВИЩЕННЯ СИЛ ТЕРТЯ МІЖ ШАРАМИ ТАРНИХ ВАНТАЖІВ
}

\author{
А. В. Деренівська, канд. техн. наук \\ Л. О. Кривопляс-Володіна, д-р техн. наук \\ С. В. Токарчук, канд. техн. наук \\ Національний університет харчових технологій
}

Проведене дослідження з використанням методу підвищення сил тертя між шарами тарних вантажів дає змогу визначити характерні параметри, які убезпечуватимуть взаємне переміщення тарних вантажів, забезпечуватимуть стійкість пакета за умови виконання навантажувально-розвантажувальних транспортно-складських робіт, підібрати відповідний пакетувальний засіб, спростити схему технологічного процесу пакетування та зменшити час кінематичного циклу пакетоформувальної машини.

Ключові слова: транспортна упаковка, пакетоформувальні машини, засоби скріплення, стійкість, шар.

Постановка проблеми. Найбільш поширений і продуктивний метод організації переміщення харчової продукції, що дає змогу комплексно механізувати весь процес навантажувально-розвантажувальних транспортно-складських робіт, а також вилучити зайві операції, скоротити простій і підвищити продуктивність транспортних засобів і перевантажувальних механізмів — це пакетування.

Пакетування передбачає об'єднання (формування) вантажів у транспортний пакет, тобто створення вантажної одиниці вкладанням тарних вантажів (коробок, ящиків, мішків, групових упаковок у термоусаджувальній або розтягувальній плівці) 3 продукцією на піддон, що забезпечує їхню цілісність і збереження [1; 2].

Для проведення технологічної операції пакетування використовуються пакетоформувальні машини, які повинні забезпечувати безперебійне пакетування тарних вантажів відповідно до продуктивності дозувально- фасувального та іншого обладнання і внутрішньозаводських транспортних систем; автоматичне вкладення вантажів у щільні пакети із заданими розмірами без ушкоджень упаковки і продукту; автоматичну подачу порожніх піддонів у зону патентування;скріплення пакетів і забезпечення їх стійкості в процесі доставки вантажу від відправника до споживача; накопичення готових пакетів на конвеєрі видачі для забезпечення безперебійної і злагодженої роботи навантажувально-розвантажувальних засобів.

Якість процесу пакетування оцінюють стійкістю - здатністю пакета зберігати надану йому форму та геометричні розміри протягом усього циклу навантажувальнорозвантажувальних транспортно-складських робіт.

Стійкість транспортного пакету залежить від:

- способу вкладання вантажних одиниць на піддоні;

- механічних параметрів матеріалів засобів використаних під час пакування та пакетування;

- способу скріплення транспортного пакета;

- точності виконання операцій у пакетоформувальній машині. 
На стійкість пакета впливає також його міцність, яка пов'язана, перш за все, 3 міцністю групової та споживчої упаковки, що обмежує висоту стопи або штабеля в пакеті.

Проблема забезпечення надійної стійкості і міцності транспортних пакетів $\epsilon$ першочерговою в системі наскрізних перевезень вантажів. Для скріплення транспортних пакетів (рис. 1) та надання їм стійкості застосовують одноразові або багатообігові конструкції.

Аналіз засобів скріплення показує, що багатообігові засоби (стропи, стяжки, касети тощо) мають низку недоліків: характеризуються більшою вартістю, трудомісткістю під час виготовлення та потребують ремонту; повернення постачальнику продукції, що ускладнює їх використання. До того ж під час використання багатообігових засобів скріплення на сьогодні не повністю вирішене питання механізованого й автоматизованого скріплення пакетів. Це значною мірою знижує ефективність застосування багатообігових засобів скріплення. Особливо це відчутно в умовах серійного та масового виробництва.

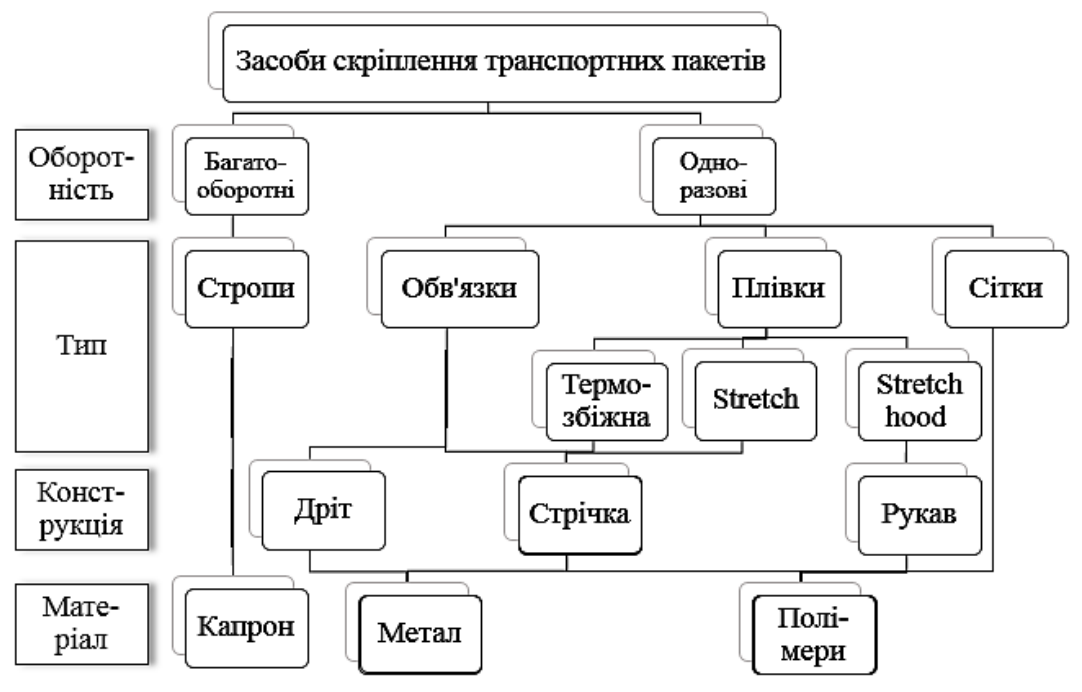

Рис. 1. Класифікація засобів скріплення транспортних пакетів

Одноразові засоби скріплення пакетів (сталева та полімерна стрічки, клеї, дріт, термоусаджувальна та розтягувальні - Stretch, Stretchhood, - плівки, сітки 3 полімерних стрічок) більш широко використовуються завдяки їх різноманітному асортименту.

Найбільш ефективним, з точки зору надійності скріплення транспортних пакетів, захисту виробів від шкідливих дій зовнішнього середовища, універсальності, економічно доцільним і ресурсоощадним $\epsilon$ спосіб із застосуванням розтягувальних плівок.

Технології на їх основі потребують значно менших, ніж при термоусаджуванні, енерговитрат і полімерної сировини.

Однак використання для пакетоформування розтягувальної плівки має і ряд недоліків [3]: 
1. Найкраще скріплює пакети тільки правильної геометричної форми (це $85 \%$ від загального обсягу).

2. Напруження розтягу, що виникає в плівці, змінюється в часі по експоненті, а вона працює в умовах постійного значення відносного видовження. Поступово зусилля стягування буде зменшуватися, і тим швидше, чим вище температура навколишнього середовища, адже зі збільшенням температури релаксаційні процеси прискорюються. Тому слід враховувати що, при підвищенні температури під час перевезення щільно скріпленого транспортного пакета розтягувальною Stretch плівкою, можна отримати його деформацію або руйнування спричинені зменшенням величини зусилля стягування [4].

3. Підвищення ресурсо- та енерговитрат, за умови забезпечення потрібної цності, шляхом накладання додаткового числа шарів.

4. Необхідність забезпечення точного виконання технологічного процесу пакетоформування робочими органами та пошуку їх оптимальних параметрів.

5. Необхідність підбору плівки залежно від багатьох факторів (параметрів зміни умов навколишнього середовища, режимів і параметрів роботи робочих органів пакетоформувальної машини).

Види можливих змін форми транспортного пакета, скріпленого різними засобами пакетування, зумовлені впливом інерційних складових під час транспортування зображені на рис. 2. Ці зміни (найчастіше деформації) можуть бути не тільки пластичними, а й еластичними (пружними), тобто коли при припиненні впливу інерційної сили форма транспортного пакета відновлюється без пошкодження вантажу всередині. Більш того, пластична деформація може бути незначною, коли після припинення дії інерційної сили форма відновлюється, але не повністю, хоча й без критичних деформацій тарних вантажів всередині.
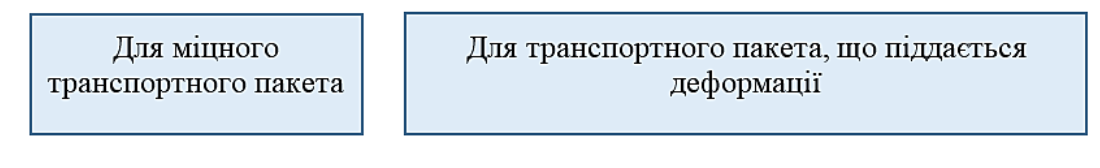

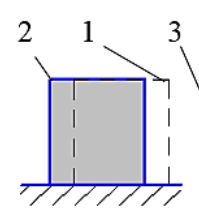

$a$

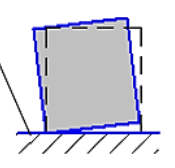

6

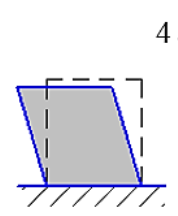

e

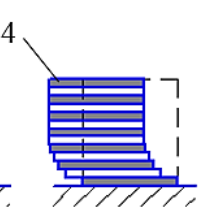

2

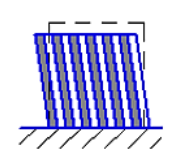

$\partial$

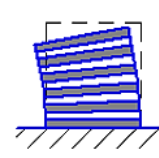

$e$

Рис. 2. Вид можливих змін форми транспортного пакета під дісю сил інерції:

$a$ - ковзання, $\sigma-$ перекидання, $b-$ зміна форми, $2-$ зсування, $\partial-$ нахил, $e-$ зминання;

1 - початкова форма групи тарних вантажів на піддоні, 2 - зміна форми групи тарних вантажів на піддоні, 3 - поверня піддону, 4 - шар тарних вантажів

При переміщенні зміна форми транспортного пакета відбувається за рахунок зміни силового навантаження: сили інерції шару тарних вантажів; сил тертя між шарами вантажів; сили тертя між пакетом і опорною поверхнею піддона. Для вище розглянутих засобів і технології пакетування існує ймовірність зміщення тарних вантажів, їх шарів, групи тарних вантажів відносно піддону та справедливе тверд- 
ження: якщо сили інерції перевищують сили тертя, можливе зміщення шарів вантажів у пакеті або загалом пакета відносно опорної поверхні піддона. Для убезпечення переміщення вантажних одиниць у пакеті можна використовувати їх склеювання між собою. Такий метод значно ускладнює технологічний процес розбирання пакета, вантажі при розбиранні пошкоджуються і втрачають товарний вигляд.

Існує інший метод надання стійкості пакета не за рахунок стягування групи вантажів різними пакувальними засобами. Цей метод забезпечує стійкість пакета шляхом збільшення сил тертя між шарами та між шаром і опорною поверхнею піддона. На сьогодні він $є$ єдиним, що мало досліджений і таким, що убезпечує від зміщення тарні вантажі із збереженням їхньої цілісності.

Мета статті: дослідження та визначення характерних параметрів, які убезпечують взаємне переміщення тарних вантажів і забезпечують стійкість пакета за умови виконання навантажувально-розвантажувальних транспортно-складських робіт.

Розвиток пакувальних матеріалів і технічного оснащення пакувальної галузі зробив можливим розширення сфери засобів для скріплення транспортних пакетів. Була розроблена прокладка для запобігання ковзанню Non-SlipSafetyGripforPallets, яка використовується для підвищення стійкості транспортних пакетів за рахунок зменшення або усунення переміщення тарних вантажів в шарах. Цього вдалося досягти, покривши обидві сторони паперу акрилом на водній основі, щоб надати протиковзальні характеристики (рис. 3). Кут тертя ковзання вантажних одиниць по поверхні прокладки Non-Slip заявлено $50^{\circ}$ [5].

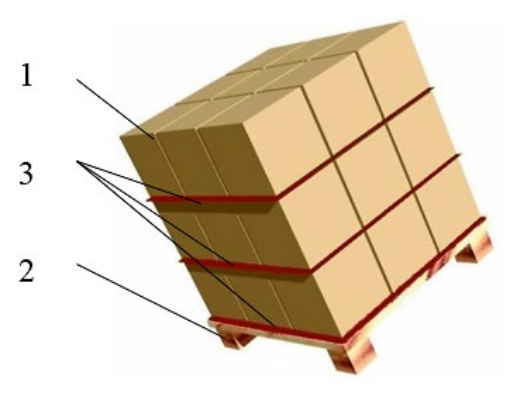

Рис. 3. Схема скріплення транспортного пакета за допомогою прокладки Non-SlipSafetyGripforPallets:

1 - гофроящик; 2 - піддон; 3 - прокладки для запобігання ковзанню продукції

Матеріали і методи. Матеріал дослідження - прокладки для запобігання ковзанню вантажів та надання стійкості транспортного пакета без використання додаткових засобів скріплення: розтягувальної стрічки, термозбіжної стрічки, художньої стрічки, строп, клею тощо.

Предмет дослідження - зміна значень сил тертя між шарами продукції залежності від кінематичних і динамічних параметрів переміщення транспортного пакета.

Необхідна умова переміщення транспортного пакета з використанням прокладки проти ковзання Non-Slip - взаємне переміщення вантажних одиниць в пакеті не повинно відбуватись. Відповідно до умови можна зробити припущення, що шари продукції є суцільним тілом. 
Результати досліджень. Під час проведення дослідження була розроблена схема силового навантаження на шари продукції (рис. 4) для забезпечення їх стійкості за допомогою сил тертя, які виникають між ними та прокладками NonSlipSafetyGripforPallets.

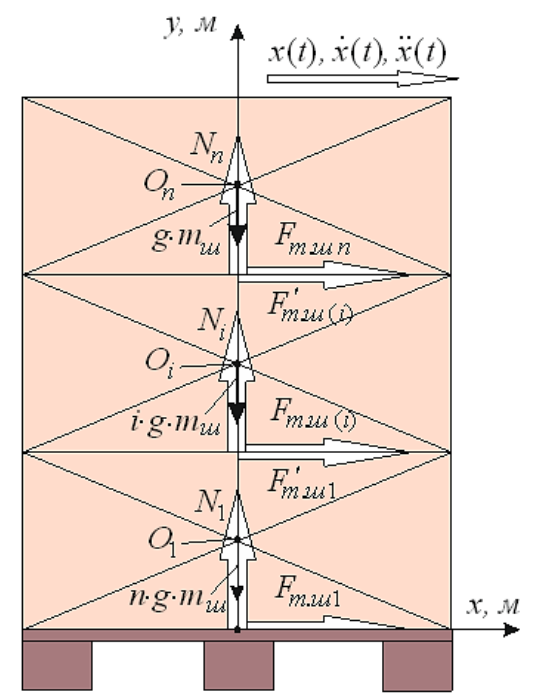

Рис. 4. Схема силового навантаження на шари тарних вантажів у транспортному пакеті

Силове навантаження яке діє на шари тарних вантажів у пакеті:

Сила тертя ковзання між шаром і прокладкою Non-Slip:

$$
\left\{\begin{array}{l}
F_{m . u 1}=f_{m . \kappa} \cdot n \cdot m_{u} \cdot g \\
F_{m . u 1}^{\prime}=F_{m . u 2}=f_{m . \kappa} \cdot(n-1) \cdot m_{u} \cdot g, \\
F_{m . u 2}^{\prime}=F_{m . u 3}=f_{m . \kappa} \cdot(n-2) \cdot m_{u} \cdot g, \\
\cdots \\
F_{m . u(i)}^{\prime}=f_{m . \kappa} \cdot(n-i) \cdot m_{u} \cdot g \\
F_{m . u(i)}=f_{m . \kappa} \cdot(n-i+1) \cdot m_{u} \cdot g
\end{array}\right.
$$

де $F_{m . u 1}, F_{m . m 2}, F_{m . u 3} \ldots F_{m . m(i)}$ - сила тертя ковзання між низом шару та прокладкою Non-Slip, $H$;

$F_{m . u 1}^{\prime}, F_{m . m 2}^{\prime}, F_{m . u 3}^{\prime} \ldots F_{m . u(i)}^{\prime}-$ сила тертя ковзання між верхом шару та прокладкою Non-Slip, $H$;

$i=1,2 \ldots n-$ порядковий номер шару, починаючи від піддону;

$n$ - кількість шарів у транспортному пакеті.

Сила інерції шару тарних вантажів:

$$
F_{i н 1}=F_{i н 2}=F_{i н 3}=\ldots=F_{i H(i)}=m_{u} \cdot a_{\max },
$$

де $m_{u}$ - маса шару в транспортному пакеті, к2;

$a_{\max }$ - максимальне прискорення(динамічне навантаження), яке виникає під час проведення навантажувально-розвантажувальних транспортно-складських робіт: 


$$
a_{\max }=k_{\partial} \cdot g
$$

$k_{\partial}$ - коефіцієнт динамічного навантаження (див. табл.).

Таблиця. Коефіціснт динамічного навантаження

\begin{tabular}{|c|c|}
\hline Частки від величини навантаження g, м/ с $^{2}$ & $k_{\partial}$ \\
\hline Переміщення автотранспортом & 1,5 \\
\hline Переміщення повітряним транспортом & 3,5 \\
\hline Переміщення водним транспортом & 1 \\
\hline Вплив при виконанні перевантажувальних операцій & 3,5 \\
\hline
\end{tabular}

Необхідна умова виконання навантажувально-розвантажувальних транспортноскладських робіт із збереженням стійкості транспортного пакета:

$$
F_{m . m(i)}^{\prime}+F_{m \cdot u(i)} \geq F_{i н(i)} .
$$

Використовуючи необхідну умову (4) та системи рівнянь (1), (2) та (3), можна визначити необхідні значення коефіцієнтів тертя ковзання, що утримуватимуть різні шари транспортного пакета та забезпечуватимуть його міцність і стійкість:

$$
\left\{\begin{array}{l}
f_{m . \kappa 1}=\frac{k_{\partial}}{2 n-1} ; \\
f_{m . \kappa 2}=\frac{k_{\partial}}{3-2 n} ; \\
\cdots \\
f_{m . \kappa(i)}=\frac{k_{\partial}}{1-3 \cdot i+2 \cdot n},
\end{array} .\right.
$$

Результати проведеного математичного моделювання представлені графіками на рис. $5-8$.

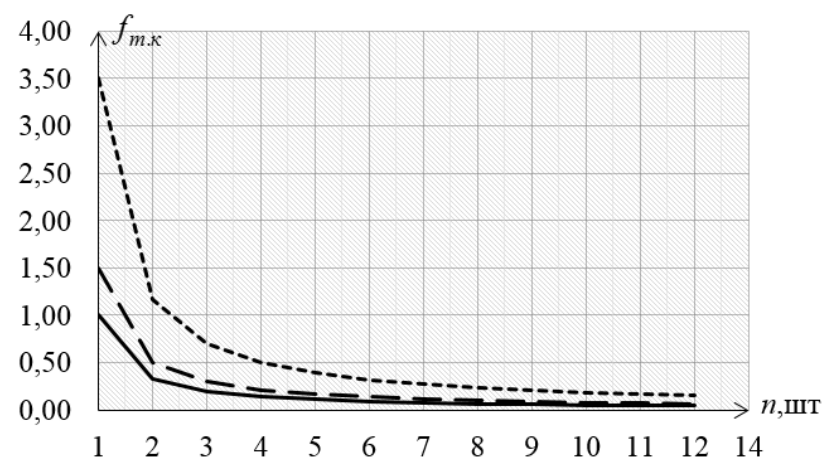

Рис. 5. Графік зміни необхідного значення коефіціснта тертя ковзання для першого шару вантажних одиниць, що забезпечуватиме його стійкість, залежно від загальної кількості шарів у транспортному пакеті та динамічного навантаження на пакет:

$$
k_{\partial}=1 ; \quad-\quad---k_{\partial}=1,5 ;
$$$$
k_{\partial}=3,5
$$ 


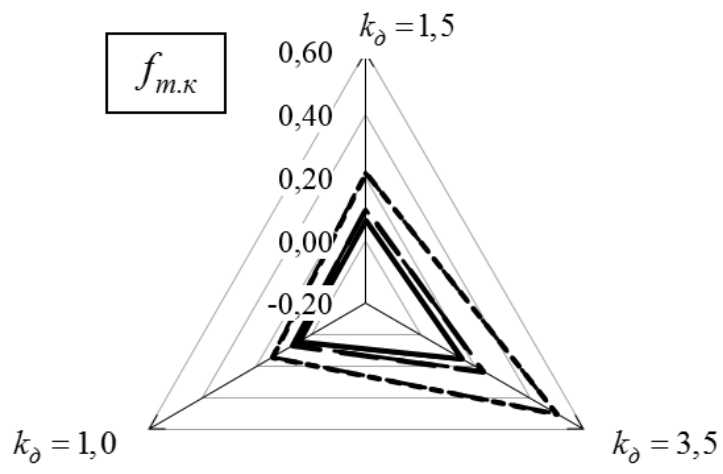

Рис. 6. Графік зміни необхідного значення коефіціснта тертя ковзання для першого шару вантажних одиниць, що забезпечуватиме його стійкість, залежно від загальної кількості шарів у транспортному пакеті та динамічного навантаження на пакет: $n=12$;

$----^{n}=8$ $n=4$.

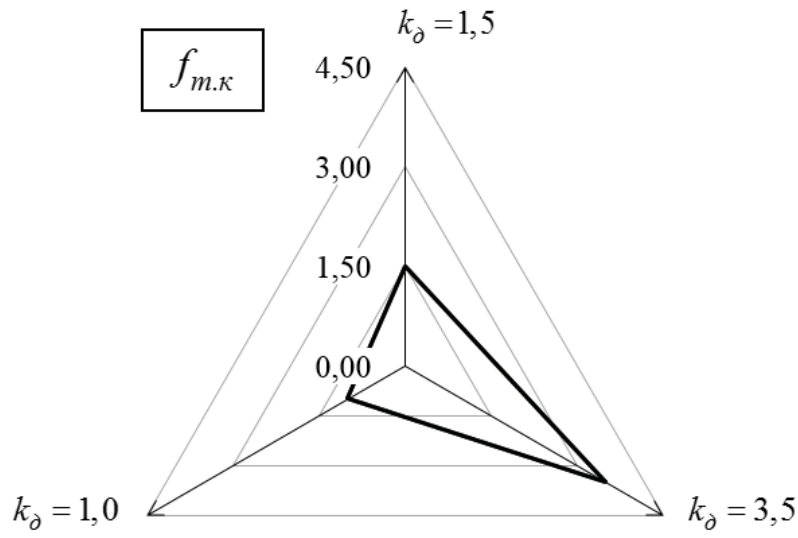

Рис. 7. Графік зміни необхідного значення коефіціснта тертя ковзання для верхнього шару вантажних одиниць, що забезпечуватиме його стійкість

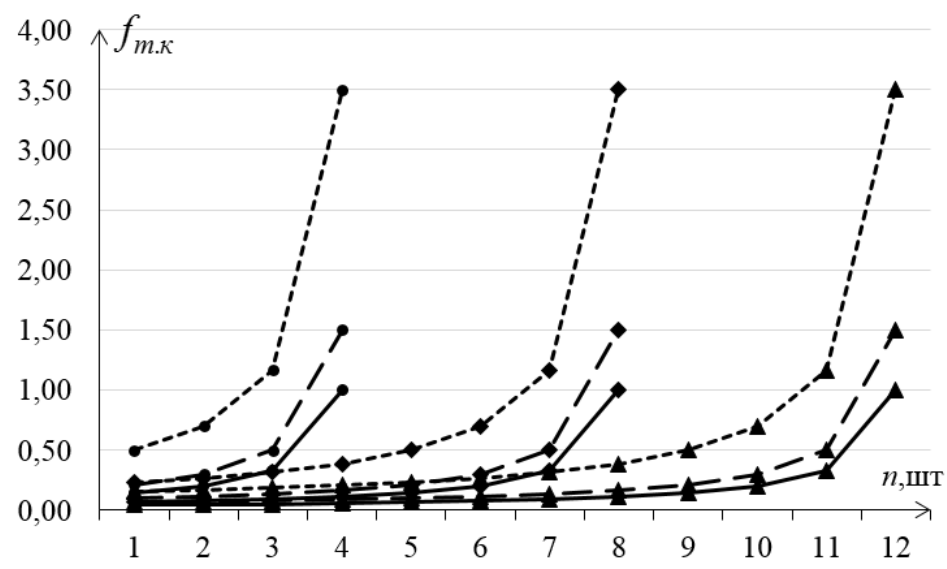

Рис. 8. Графік зміни сил тертя в між шарами продукції при переміщенні транспортного пакета 3 динамічним навантаженням:

$$
k_{\partial}=3,5 ; \quad---k_{\partial}=1,5 ;
$$$$
k_{\partial}=1,0
$$ 
Заявлений коефіцієнт тертя ковзання вантажних одиниць по прокладці становить $\operatorname{tg}(50)=1,19$. Згідно з проведеним дослідженням (рис. 5-8), під час виконання перевантажувальних операцій слід уникати високих динамічних навантажень, а при транспортуванні автотранспортом, повітряним транспортом слід користуватися додатковими пакувальними засобами (наприклад, повітряними пакетами). Ці обмеження також справедливі і для інших видів скріплення транспортного пакета, тому використання прокладок Non-Slip є перспективним і технологічно виправданим.

Висновок. Визначення необхідних коефіцієнтів тертя на різних етапах переміщення, які забезпечуватимуть стійкість шарів продукції в транспортному пакеті, дасть змогу раціонально підібрати вид прокладки для запобігання ковзанню цих шарів, спростити схему технологічного процесу пакування і зменшити час кінематичного циклу: не потрібно використовувати різні способи укладки в шарах продукції та витрачати час на зняття додаткових засобів скріплення.

\title{
ЛІТЕРАТУРА
}

1. Гавва О. М. Скріплення транспортних пакетів стрічками (матеріали, технології та обладнання) / О. М. Гавва, А. П. Беспалько // Упаковка. — 2014. — № 5. — С. 45-50. — Режим доступу: http://nbuv.gov.ua/UJRN/Upakovka_2014_5_11.

2. Беспалько А. П. Обладнання для скріплення транспортних пакетів (стан, перспективи, тенденції розвитку) / А. П. Беспалько, О. М. Гавва, С. В. Токарчук // Упаковка. — 2010. № 2. - С. 54-58. - Режим доступу:http://dspace.nuft.edu.ua /jspui/handle/123456789/3757.

3. Беспалько А. П. Термоусаджувальна та розтягувальна плівки у пакуванні. Що вибрати? / А. П. Беспалько, О. М. Гавва, С. В. Токарчук // Упаковка. — 2015. - № 3. - С. 12-15. Режим доступу: http://nbuv.gov.ua/UJRN/Upakovka_2015_3_4.

4. «Обманчивая» стретч-пленка. - Режим доступу:http://www.baif.by/stati/ krepleniegruzov-obmanchivaya-stretch-plenka-1/.

5. RETHINK PALLETIZATION. UseGripSheets. — Режим доступу:https://www. Gripsheetamerica.com/.

\section{ОПРЕДЕЛЕНИЕ РАЦИОНАЛЬНЫХ ПАРАМЕТРОВ ОБЕСПЕЧЕНИЯ УСТОЙЧИВОСТИ ТРАНСПОРТНОГО ПАКЕТА МЕТОДАМИ ПОВЫШЕНИЯ СИЛ ТРЕНИЯ МЕЖДУ СЛОЯМИ ТАРНЫХ ГРУЗОВ}

\author{
А. В. Дереновская, Л. А. Кривопляс-Володина, С. В. Токарчук \\ Национальный университет пищевых технологий
}

Проведенное исследование с использованием метода повышения сил трения между слоями тарных грузов позволяет определить характерные параметры, которые будут предупреждать взаимное перемещение тарных грузов, обеспечивать устойчивость пакета при условии выполнения погрузочно-разгрузочных транспортно-складских работ, выбрать соответствующее средство пакетирования, упростить схему технологического процесса пакетирования и уменьшить время кинематического цикла пакетоформирующей машины.

Ключевые слова: транспортная упаковка, пакетоформирующая машина, средства крепления, устойчивость, слой. 